\title{
Unveiling Trends in Cultural Participation: The Case of Slovakia
}

\author{
Miriam Šebová * (1) and Zuzana Révészová \\ Department of Regional Science and Management, Faculty of Economics, Technical University of Košice, \\ 04001 Košice, Slovakia; zuzana.reveszova@tuke.sk \\ * Correspondence: miriam.sebova@tuke.sk
}

Received: 8 August 2020; Accepted: 19 October 2020; Published: 27 October 2020

\begin{abstract}
This paper explores the trends in participation in a variety of cultural activities in Slovakia. Although the research on cultural participation has thrived and there have been plenty of empirical studies published about the consumption of cultural products in different countries, there is still a lack of comprehensive research from former post-communist countries. The paper aims to test the link between cultural participation and social and economic characteristics, which has previously been done in other international studies. The cluster analysis suggests four types of Slovak cultural participants-the heritage visitors, the omnivores, the popular genre visitors, and the inactive. The outcomes point to a strong relationship between cultural inactivity and heritage visits to socioeconomic status, while there is a weak relationship between highbrow cultural participation and the upper-class. The results challenge cultural policies to be adjusted for different groups of cultural participants with the objective of increasing the overall consumption of cultural goods in Slovakia.
\end{abstract}

Keywords: cultural participation; typology; latent class cluster analysis

\section{Introduction}

Previous research on cultural participation has mostly been based on national surveys e.g., (Chan and Goldthorpe 2007), (Bihagen and Katz-Gerro 2000), (Purhonen et al. 2011), (Sintas and Álvarez 2002), (López-Sintas and Katz-Gerro 2005); (Suarez-Fernandez et al. 2020), limiting the possibility of making international comparisons. As the quality of available data at the European level has increased, several studies with supernational data have been published e.g., (van Hek and Kraaykamp 2013), (Gerhards 2008), (Notten et al. 2015). Despite the problems that persist with establishing internationally comparable statistics on cultural participation, there has been significant progress in cultural statistics at the EU level in recent years ( $\mathrm{O}^{\prime}$ Hagan 2017a).

European-level research has been dominated by the West with a lack of studies from post-socialist countries (Katz-Gerro 2011). After 1989, several studies by Western authors also compared Central and Eastern Europe (CEE), e.g., De Graaf (1991), Kraaykamp and Nieuwbeerta (2000). However, research done by authors in CEE and based on primary data has been relatively rare. Cultural participation in Slovakia has mainly been a side topic in larger research studies focused on lifestyle or social stratification (Chorvát and Šafr 2020).

Bukodi (2007) discussed post-socialist patterns of cultural participation based on data collected by the Hungarian Statistical Office in 2000. In addition, Šafr (2006) published a sociological study on lifestyle differentiation, cultural consumption, and social stratification in the Czech Republic.

When comparing the research of European and post-socialist countries, there are evident differences in the form of cultural capital. In other words, different social evolution and specific national contexts lead to diverse patterns of cultural consumption. 
Indeed, it seems that income has a larger impact on cultural participation in CEE countries than in Western Europe (Bukodi 2007). The results of Eurobarometer research in 2013 noted a decrease in cultural participation in CEE countries in comparison to pre-crisis 2007 figures. This decrease can be explained by the higher sensitivity to income. Earlier research has also concluded that the social status of parents is an important variable in CEE countries (Kraaykamp and Nieuwbeerta 2000; De Graaf 1991).

The goal of this paper is to explore how Slovak people consume culture and which characteristics shape the frequency and way of participation.

There are two research questions posed in the paper. First, we want to shed light on the types of cultural consumers in Slovakia based on the different forms of cultural participation and look at their educational capital and other socio-economic characteristics. Cluster analysis was carried out and the consumption pattern in each cluster explained.

Secondly, we want to compare the results between 2007 and 2013 in order to analyze if the cultural consumption patterns changed or remained stable. While it is a short time period, two significant factors could have influenced cultural participation. The first one is the financial crisis, which negatively affected the national cultural policy. The second one is the designation of the second largest city Košice in Eastern Slovakia as European Capital of Culture in 2013. The project achieved culture-led urban regeneration and its cultural activities and events were covered intensely by local as well as national media. (Hudec et al. 2015) Therefore, we want to test if there were any changes in the region of Košice.

The first part of the article reviews the existing literature in the field of cultural participation with a special emphasis on comparative research and research in Central and Eastern Europe. The methodological part presents data from the Eurobarometer and a short description of the used method Latent Class Cluster Analysis. In the analytical part, the typology is explained. The characteristics of the clusters, the size, and the typical patterns of cultural behavior are then presented.

The data stem from two Eurobarometer surveys (Eurobarometer 2007, 2013). Although the study uses older data, they have allowed us to achieve results comparable with other European countries as well as Eurobarometer surveys in the future. The Eurobarometer data enable comparisons within the timespan, even though the variables that the survey offers may be limited and a more thorough analysis of cultural participation is not possible.

As the first study of its kind from Slovakia, the contribution lies in the inclusion of Slovakia in the theoretical analysis of cultural participation in relation to the socio-economic status of individuals. It also adds to the context of Central and Eastern Europe, which still faces similar problems in cultural policy linked to the post-communist transformation (Vojtíšková and Lorencová 2014). In terms of the "post-Bourdieu debate", the findings have confirmed that higher class behavior is related more to omnivorous cultural consumption although it does not predict any form of cultural participation.

\section{Defining and Debating Cultural Participation}

Cultural participation has been conceptualized in different ways using the terms art participation and cultural consumption. The debate begins with Bourdieu (1984) who developed the "cultural reproduction theory" in his seminal work 'Distinction'. His theory claimed that cultural preferences and behavior were the result of belonging to a particular social class and education system. Culture is understood as a tool that enables relational positionality in the social field and therefore a set of intellectual capacity with which one disposes in social interactions (Bourdieu 1984). Later, DiMaggio (1982) introduced the "cultural mobility theory" that explains that it is possible to gain cultural capital throughout one's lifetime and that cultural capital can be transformed. The concept of cultural homogeneity dominated the literature until the 1990s. At that time, Peterson and Simkus (1992) used data from the National Survey of Public Participation in the Arts to analyze cultural preferences. They connected the musical preferences of Americans with social position (gender, employment) rather than social class in the Bourdieusian sense (Peterson and Simkus 1992). They found that people 
of higher income and cultural education (so-called "snobs") not only visited events of high-brow culture (opera, classical music concerts) more often but also tended to visit genres of low-brow culture such as rock and jazz in their leisure time. This phenomenon was caused by the social changes and growing heterogeneity of culture (Peterson and Simkus 1992). They formulated an alternative approach to the strict division between consumers of high-brow and low-brow culture-snob vs. slob. The group of people with higher incomes and social status that visited various cultural genres were called omnivores while the group of lower-income people that rarely visited culture and if so, only of a single genre, were called univores. This group is differentiated from the group of completely inactive people in cultural participation. The basic division of omnivores and univores was gradually developed in other empirical studies with the aim of creating a typology of cultural visitors (Vander Stichele and Laermans 2006), (Sintas and Álvarez 2002). In their research on visual arts in England, Chan and Goldthorpe (2007) described univores as those that would usually prefer the cinema in the genre "theatre, cinema, dance". However, if they narrowed the category to live performances only, these people would be culturally inactive. The univores can like a genre of popular culture as much as a genre of high-brow culture (Chan and Goldthorpe 2007). Other typologies have been developed using different approaches to cultural participation. Weingartner and Rössel (2019) discuss the differentiation between "non-participation" and "participation" as the primary distinction for the analysis of social field in relation to culture. Roose et al. (2012) have additionally used the dimensions of openness and adventure in creating a typology of participants. In their approach, openness is therefore associated with the omnivores in contrast to the more conservative univores (Roose et al. 2012). Reeves (2014) discusses the differences between "passive" and "active" participation and their tendency to interconnect when creating typologies of participants-social class is mainly demonstrated by passive cultural participation. Warde et al. (2007) have characterized four groups of cultural consumers based on deeper qualitative research in interviews about cultural behavior, doubting that participation as such can predict social distinctions, if the content of the visit is not clarified. The created typology comprised: High-brow univores who have narrow cultural taste and prefer "elite" culture; high-brow omnivores who have a wide range of cultural preferences; low-brow univores who have narrow cultural taste and prefer genres of popular culture; and low-brow omnivores who have a wide range of cultural preferences.

Chan and Goldthorpe (2007) created another two groups in addition to the omnivores and univores called the paucivores (people who consume only a limited amount of cultural activities) and the inactive (people who do not partake in cultural activities). The weak consumers (paucivores) is a group that has weaker cultural participation than the omnivores. However, they do visit more cultural activities in a limited capacity although it is not possible to identify if only higher or only popular forms (Chan and Goldthorpe 2007).

Most research has focused on clarifying the main factors that determine cultural participation. These studies have demonstrated that belonging to a social class is the main factor in forming cultural taste (Bukodi 2007); (Vander Stichele and Laermans 2006); (van Hek and Kraaykamp 2013). The patterns of cultural participation strongly correlate with individual socio-economic characteristics (Katz-Gerro 2011).

Research has also shown a consensus on the key role of education as a forming factor in cultural capital (Notten et al. 2015; O'Hagan 2017b; Suarez-Fernandez et al. 2020). Education remains strongly correlated with most forms of cultural participation and this factor primarily explains cultural participation as part of people's lifestyle (Reeves 2014). Other factors are the level of income, the type of economic activity (employed, unemployed, retired, etc.), and location (living in a city or a village) (Hallmann et al. 2017).

The intensity of the impact of each factor can differ depending on nationality. Coulangeon (2005) analyzed the impact of education on high-brow culture consumption in the EU 15. The explanatory impact of education on the increase of high-brow consumption was shown to be higher in the countries that have a relatively high ratio of university-educated people (Coulangeon 2005). Moreover, 
the explanatory impact of income was lower in the countries that have invested much more into cultural policy such as Scandinavia (Falk and Katz-Gerro 2015). Higher education, higher income, and prestigious professions have all been connected to greater active cultural participation.

Age has also been shown to be a dominant variable (Sintas and Álvarez 2002) on cultural participation. In the USA and UK, older people have been found to be more culturally active, whereas younger people in the Netherlands are more active as well as more culturally omnivore. In Hungary, older people have been found to be less active, or only active in classical genres (Katz-Gerro 2011). Studies have not shown complete agreement in terms of gender. The difference is visible with women on maternity leave or with children, who naturally have a lower consumption of culture.

There is also the role of place. People from bigger cities consume more culture in comparison with those in the countryside. This is mainly connected to the access to cultural infrastructure. As such, improving access could have a strong positive relationship on attendance (Brook 2016). A study about the geography of libraries has revealed the significant impact of spatial aspects and asset "attractiveness" on particular kinds of cultural participation (Delrieu and Gibson 2017).

The introduction of digital media has brought new perspectives into research about cultural participation as it is seen as an instrument of increasing participation and diversity. Recent research has claimed that digital media provides an important means of engaging new audiences (Mihelj et al. 2019).

The difference between the weight of factors has been shown at the level of different countries and in diverse cultural genres-mainly in the traditional division of high-brow and low-brow culture. High-brow culture is canonical and stable, easier to define, and also more often selected to be the object of scientific inquiry. Lower forms of culture are diverse and continuously transform, making them more complicated to analyze thoroughly. However, it remains evident that high-brow cultural genres (opera, ballet, philharmonics) are only visited by a minority of the population. On the other hand, half of the population in the EU 27 visits historical-cultural heritage as well as the cinema (Katz-Gerro 2011).

Another factor that is considered to be important in cultural participation is the model of cultural policy e.g., (Falk and Katz-Gerro 2015; Katz-Gerro 2017). Models of cultural policy in European countries differ in institutional guarantee, financial help (financial tools, size of the budget), and concepts (support of excellent forms of art, political goals, and social wealth). Cultural participation should be a crucial aspiration of cultural policy and its role has been debated by Jancovich and Stevenson (2019).

\section{Cultural Participation in Slovakia}

So far, post-socialist cultural policy has been largely neglected. There has been a very limited budget since 1989 in Slovakia, with especially tough budget cuts in the reformist times 1998-2006 (Denel 2003). Methodologically, cultural policies have also lacked the effort to do systematic data analysis and cultural participation research.

There were no national surveys carried out regarding cultural participation after 1989 until Slovakia was involved in the first Eurobarometer research in (Eurobarometer 2007) The only available data about culture were reported by the individual cultural institutions and from them it has not been possible to understand the bigger of cultural participation at the national level. The latest Eurobarometer in (Eurobarometer 2013) found a decline in cultural participation in all types of cultural activities in Slovakia. The greatest decline in cultural participation has been in public libraries (an increase of 15\% of respondents who have not visited a library in a year), historical monuments, museums, and galleries (Eurobarometer 2007, 2013).

This has been in spite of the ever-increasing educational level of the population in Slovakia over this period. The share of the population with tertiary education was $9.4 \%$ in $1990,10 \%$ in $2000,16.7 \%$ in 2011, and 19\% in 2012 (Lauko et al. 2012) (OECD 2014). Even, the number of primary pupils in art classes slightly increased in this timespan. In 2003, 92,011 pupils took art classes after school while it was 108,983 pupils in 2019 (CVTISR 2020). 
The trend of declining cultural participation can have many explanations. There have been a number of new phenomena in the area of leisure time such as shopping centers, spending time on the internet and at a computer as well as watching TV. According to surveys, these activities have displaced the traditional forms of leisure-manual work, sports activities, outdoor activities, and cultural visits (Chorvát 2011). The current socio-cultural situation is increasingly focused on popular cultural genres and on receiving culture through the media.

In terms of active cultural participation, it is evident that the practice of amateur artistic activities also decreased over the period under review. Respondents had the opportunity to list eight types of amateur art activities. In the following analysis, these were combined into two variables-traditional art activities and art activities through new media.

\section{Research Design}

\subsection{Data and Method}

The current study has drawn on internationally comparable data from the Eurobarometer coordinated by the European Commission. The survey was conducted in Slovakia by TNS Slovakia, Bratislava. Cultural participation was a topic of two special survey Eurobarometers in (Eurobarometer 2007, 2013). Eurobarometer 67.1. "Cultural Values, Poverty and Social Exclusion, Developmental Aid and Residential Mobility" in 2007 and Special Eurobarometer 399 "Cultural Access and Participation" in 2013. One thousand respondents from Slovakia were interviewed. These are cross-sectional data as different respondents participated in the surveys. In both surveys, there were almost identical questions about cultural participation. Therefore, it is possible to observe the trend in cultural participation over this time 2007-2013.

Based on the previous literature review, it can be seen that the frequency of attending cultural events is linked to respondents' demographic and socio-economic characteristics. Therefore, the relationship between selected demographic and socio-economic variables and the attendance and frequency at types of cultural activities will be examined.

The basic part of the research regarding cultural participation is an analysis of different types of culture consumers, their classification, and estimation of group size. In older sociological studies, factor analysis was often used in cultural participation studies. Given its limitations in the investigation of qualitative (categorical) variables however, the current preference is for Latent Class Analysis (LCA) (Katz-Gerro 2011). As with factor analysis, LCA results in reducing the number of observed variables to a smaller number of latent variables.

By combining latent class analysis and cluster analysis, a latent class cluster analysis has been formulated. This first allows us to reduce the dimensions of cultural participation and then divide individuals into clusters that are similar in terms of cultural participation.

Given the similarity between the cluster method and latent class analysis, Wolfe (1970) was the first to explicitly link LCA and cluster analysis (Magidson and Vermunt 2002) and create a theoretical framework for Latent Class Cluster Analysis (LCCA). As many concepts in the social sciences are not directly observable, Latent Class Analysis (LCA) suggests that an unobserved (latent) variable explains responses among a set of observed variables. LCA analyses the responses among these observed variables and constructs a typology of the dominant patterns of arts participation (Chan and Goldthorpe 2007). As Vander Vander Stichele and Laermans (2006) have argued, LCA is one of the most appropriate ways to construct a latent typology and LCCA has been previously used in several empirical studies of cultural participation e.g., (Vander Stichele and Laermans 2006; Chan and Goldthorpe 2007; Sintas and Álvarez 2002; Van Rees et al. 1999; Widdop and Cutts 2011). The LCA can be easily extended by inclusion of exogenous variables (covariates) for example demographics (Magidson and Vermunt 2002).

Before the current analysis, we tested all variables available in the questionnaire using binary logistic regression models with dependent variables of different forms of cultural participation 
(Šebová 2017). The statistically significant variables (gender, age, educational level, etc.) entered the following cluster analysis. However, as the scope of the article is limited and we address the research question of this article to the typology, only the results of the cluster analysis are displayed.

\subsection{Variables}

The objective of the quantitative analysis was to identify the types and profiles of cultural consumers in Slovakia. Different forms of cultural participation were tested in 12 dependent variables:

- Direct participation in 7 cultural activities outside the home in the last 12 months: (1) Opera and ballet, (2) theatre, (3) cinema, (4) concert, (5) library, (6) historical sites, (7) museums and galleries

- Participation in culture through the media in the last 12 months: (8) Participation in cultural broadcasting on TV or radio, (9) reading books, (10) using the internet for cultural purposes

- Active practice of culture in last 12 months: (11) Participation in cultural activities in the form of classic art practice, e.g., playing a musical instrument, singing, dancing, theatre, poetry, painting, (12) participation in cultural activities in the form of multimedia art e.g., film-making, taking photos, creative computer work (designing internet sites or blogs etc.)

The frequency of cultural participation was also followed by combining categories from the survey (3-5 times per year and more than 5 times). Variables 1-10 were trichotomous and ordinal with the scale: Not once, 1-2 times, more than 3 times. Variables 11-12 were dichotomous: Yes, no.

Socio-economic characteristics were chosen as the independent variables (covariates), which had been shown to be statistically significant in the literature review: gender, age, education, locality, marital status, social class (2013) and material conditions (2007).

The regional perspective was included within the variable region based on the NUTS (statistical territorial units) classification. It divides the country into four regions. The Bratislava region is predominantly urban in character because the capital city is there. It is also the largest city in the country. Employment was not included as an explanatory variable as this variable does not have a significant impact when combined with the education variable (Vander Stichele and Laermans 2006). The dependent variables-indicators were entered into the model as ordinal while the covariates went in as nominal variables.

\subsection{Choice of the Model}

Since the cluster analysis of latent classes is a non-hierarchical method, the optimal number of clusters was estimated. In previous cultural participation studies, between 3 and 6 clusters have been identified e.g., Vander Stichele and Laermans (2006). Given that this study considers a greater number of cultural activities, the creation of 3-8 clusters with specified variables was tested.

Both Tables 1 and 2 summarize the parameters of the estimated 8 models according to the Eurobarometer data (Eurobarometer 2007, 2013). The study tested whether the formulated model showed significant deviations from the observed data-set and whether the proposed model could be accepted. In order to evaluate the model, the most commonly used statistical criteria was followed-Bayes Information Criterion (BIC), Akaike Information Criterion (AIC), and Consistent Akaike Information Criterion (CAIC). The smaller the values, the better the model reflects on the data used.

The model with the lowest value of monitored information criteria and at the same time optimal in terms of parsimony was chosen. Based on the values (BIC, CAIC), the model with 4 clusters was selected. In addition to the validity of the overall model, the statistical significance of the individual indicators through Wald's statistics and $p$-value were monitored. For all variables (both dependent and independent), a $p$-value lower than 0.05 was found in both the monitored years, rejecting the null hypothesis (the effects associated with the indicator are 0 ). Each variable contributes to a statistically significant degree to the ability to distinguish the clusters. 
Table 1. Results of the Test for the Estimated Cluster Models in 2007.

\begin{tabular}{cccccccc}
\hline 2007 & $\mathbf{L L}$ & $\mathbf{B I C}(\mathbf{L L})$ & $\mathbf{L}_{\llcorner}$ & $\mathbf{B I C}\left(\mathbf{L}_{\mathbf{c}}\right)$ & $\mathbf{A I C}\left(\mathbf{L}_{\mathbf{c}}\right)$ & $\mathbf{C A I C}\left(\mathbf{L}_{\mathbf{c}}\right)$ & $p$-Value \\
\hline 1-Cluster & -9633.54 & $19,418.72$ & $17,558.60$ & $10,920.98$ & $15,632.60$ & 9957.984 & 0.000 \\
2-Cluster & -8617.01 & $17,606.40$ & $15,525.72$ & 9108.668 & $13,663.72$ & 8177.668 & 0.000 \\
3-Cluster & -8381.49 & $17,355.75$ & $15,054.50$ & 8858.017 & $13,256.50$ & 7959.017 & 0.000 \\
4-Cluster & -8219.30 & $17,251.93$ & $14,730.11$ & 8754.190 & $12,996.11$ & 7887.190 & 0.000 \\
5-Cluster & -8131.87 & $17,297.64$ & $14,555.26$ & 8799.900 & $12,885.26$ & 7964.900 & 0.000 \\
6-Cluster & -8060.39 & $17,375.24$ & $14,412.29$ & 8877.499 & $12,806.29$ & 8074.499 & 0.000 \\
7-Cluster & -8016.55 & $17,508.14$ & $14,324.63$ & 9010.399 & $12,782.63$ & 8239.399 & 0.000 \\
8-Cluster & -7958.69 & $17,612.97$ & $14,208.90$ & 9115.234 & $12,730.90$ & 8376.234 & 0.000 \\
\hline
\end{tabular}

Table 2. Results of the Test for the Estimated Cluster Models in 2013.

\begin{tabular}{cccccccc}
\hline $\mathbf{2 0 1 3}$ & $\mathbf{L L}$ & $\mathbf{B I C}(\mathbf{L L})$ & $\mathbf{L}_{\boldsymbol{c}}$ & $\mathbf{B I C}\left(\mathbf{L}_{\mathbf{c}}\right)$ & $\mathbf{A I C}\left(\mathbf{L}_{\mathbf{c}}\right)$ & $\mathbf{C A I C}\left(\mathbf{L}_{\mathbf{c}}\right)$ & $p$-Value \\
\hline 1-Cluster & -8702.47 & $17,555.32$ & $15,938.29$ & 9731.940 & $14,122.29$ & 8823.940 & 0.000 \\
2-Cluster & -7602.76 & $15,574.62$ & $13,738.86$ & 7751.240 & $11,986.86$ & 6875.240 & 0.000 \\
3-Cluster & -7380.87 & $15,349.56$ & $13,295.07$ & 7526.178 & $11,607.07$ & 6682.178 & 0.000 \\
4-Cluster & -7207.04 & $15,220.64$ & $12,947.43$ & 7397.258 & $11,323.43$ & 6585.258 & 0.000 \\
5-Cluster & -7128.87 & $15,283.02$ & $12,791.09$ & 7459.643 & $11,231.09$ & 6679.643 & 0.000 \\
6-Cluster & -7052.23 & $15,348.45$ & $12,637.79$ & 7525.072 & $11,141.79$ & 6777.072 & 0.000 \\
7-Cluster & -6989.80 & $15,442.32$ & $12,512.93$ & 7618.938 & $11,080.93$ & 6902.938 & 0.000 \\
8-Cluster & -6939.86 & $15,561.18$ & $12,413.07$ & 7737.802 & $11,045.07$ & 7053.802 & 0.000 \\
\hline
\end{tabular}

Source: Authors.

\section{Results}

Both Tables 3 and 4 display the profiles in the four clusters created by cultural participation (Table 3) and socio-economic profile of the respondents (Table 4) compared according to the categories. When comparing 2007 and 2013, the only minor differences were found in the conditional probabilities that described the clusters and the character of the clusters did not change.

The size of the clusters changed slightly. The size of the clusters determines the number of cases from the sample that form the cluster. The profile of the cluster is described according to the conditional probabilities which show the differences in individual responses which determine belonging to the cluster.

Characteristics of the identified clusters

Cluster 1-Occasional visitors of historical sites (27\% respondents in $2007,24 \%$ respondents in 2013): Individuals in this cluster rarely go to cultural activities. If they do, then they visit cultural heritage sites, museums, and libraries. They mainly consume traditional forms of culture. The probability of going to the cinema was only $5 \%$ in 2013 . This group watches TV very often (the highest probability from all the clusters) and reads books. There is no relationship with new media, and the probability of using the internet for cultural purposes or practicing cultural activities connected with new media is very low. In 2007, the probability that individuals would do any form of traditional cultural activities was $60 \%$ while it was only $20 \%$ in 2013 . This cluster is mostly made up of males (probability 72\% in 2007, 77\% in 2013), middle-aged or older (85\% was over 40 in both 2007 and 2013) with secondary-school education (more than $70 \%$ of the cluster). They usually come from the countryside, small, or medium-sized towns. In comparison to the other clusters, there is only a $15 \%$ probability that these individuals come from the Bratislava Region (12\% in 2007). Individuals from this cluster are mostly married (around 70\%) or widowed. In 2007, they had a low or medium economic status, which was mirrored in 2013 when they continued to have this status. The cluster "occasional visitors of historical sites" shrunk in 2013 and the cultural activity in all areas except use of the internet for cultural purposes decreased. 
Table 3. Conditional Probabilities of Belonging to the Cluster Based on Frequency and Type of Cultural Activity.

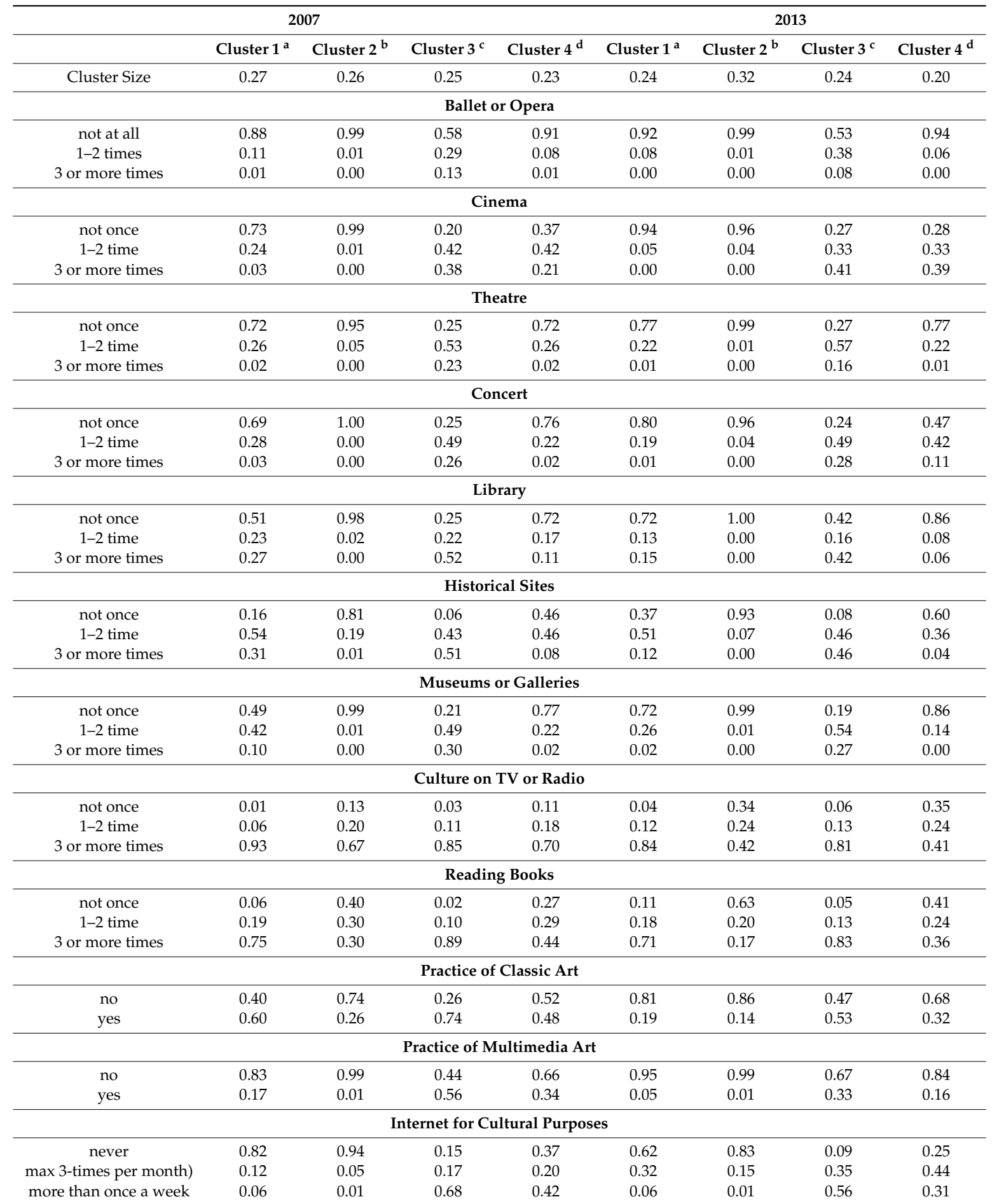

a Occasional visitors of historical sites, ${ }^{\mathrm{b}}$ Culturally inactive, ${ }^{\mathrm{c}}$ Culturally omnivorous, ${ }^{\mathrm{d}}$ Younger univorous focused on popular genres. Source: Authors. 
Table 4. Profile of Clusters Based on the Socioeconomic Characteristics of Individuals (Conditional Probabilities).

\begin{tabular}{|c|c|c|c|c|c|c|c|c|}
\hline \multicolumn{5}{|c|}{2007} & \multicolumn{4}{|c|}{2013} \\
\hline Cluster & Cluster $1^{a}$ & Cluster $2^{b}$ & Cluster $3^{c}$ & Cluster $4^{\mathrm{d}}$ & Cluster $1^{a}$ & Cluster $2^{b}$ & Cluster $3^{c}$ & Cluster $4^{\mathrm{d}}$ \\
\hline \multicolumn{9}{|c|}{ Gender } \\
\hline Women & 0.72 & 0.60 & 0.68 & 0.44 & 0.77 & 0.56 & 0.63 & 0.39 \\
\hline \multicolumn{9}{|c|}{ Age } \\
\hline $40-49$ & 0.17 & 0.17 & 0.21 & 0.23 & 0.21 & 0.21 & 0.15 & 0.15 \\
\hline $50-64$ & 0.44 & 0.36 & 0.20 & 0.10 & 0.39 & 0.41 & 0.25 & 0.10 \\
\hline 65 and over & 0.25 & 0.36 & 0.05 & 0.00 & 0.25 & 0.21 & 0.07 & 0.00 \\
\hline Educational level & 0.86 & & & & 0.85 & & & \\
\hline Primary school & 0.20 & 0.39 & 0.04 & 0.09 & 0.15 & 0.35 & 0.01 & 0.06 \\
\hline \multicolumn{9}{|c|}{ Locality } \\
\hline Countryside or village & 0.48 & 0.57 & 0.30 & 0.43 & 0.37 & 0.59 & 0.37 & 0.35 \\
\hline Small or mid-sized town & 0.44 & 0.30 & 0.48 & 0.37 & 0.52 & 0.36 & 0.45 & 0.41 \\
\hline $\begin{array}{c}\text { Bigger city (more than } \\
100,000 \text { inhabitants) }\end{array}$ & 0.08 & 0.13 & 0.22 & 0.19 & 0.11 & 0.05 & 0.18 & 0.24 \\
\hline \multicolumn{9}{|c|}{ Region } \\
\hline Bratislava region & 0.04 & 0.06 & 0.15 & 0.10 & 0.06 & 0.03 & 0.08 & 0.27 \\
\hline Western Slovakia & 0.29 & 0.38 & 0.31 & 0.43 & 0.27 & 0.29 & 0.33 & 0.28 \\
\hline Middle Slovakia & 0.30 & 0.19 & 0.27 & 0.24 & 0.33 & 0.35 & 0.26 & 0.29 \\
\hline Eastern Slovakia & 0.37 & 0.36 & 0.27 & 0.22 & 0.34 & 0.32 & 0.33 & 0.16 \\
\hline Working class & 0.22 & 0.47 & 0.01 & 0.04 & Low & 0.75 & 0.18 & 0.31 \\
\hline Middle class & 0.64 & 0.45 & 0.29 & 0.50 & Moderate & 0.25 & 0.76 & 0.65 \\
\hline Upper class & 0.15 & 0.07 & 0.70 & 0.45 & High & 0.00 & 0.06 & 0.04 \\
\hline
\end{tabular}

${ }^{\mathrm{a}}$ Occasional visitors of historical sites, ${ }^{\mathrm{b}}$ Culturally inactive, ${ }^{\mathrm{c}}$ Culturally omnivorous, ${ }^{\mathrm{d}}$ Younger univorous oriented on popular genres.

Cluster 2-Culturally inactive (26\% in $2007,32 \%$ in 2013$)$ : The second cluster is made up of culturally inactive respondents. They hardly visit any cultural events except historical sites. Visiting sites is the most probable type of culture in this cluster (7\% in 2013,19\% in 2007). The lowest probability is watching cultural programs on TV or reading. In this group, there was the lowest rate of taking part in amateur culture (there was a $26 \%$ probability that the individuals in this cluster would practice any cultural activity in 2007 while it was only $14 \%$ in 2013). The probability of using the internet for cultural purposes also has a very low probability (only $14 \%$ ).

The features of this cluster are similar to those in Cluster 1 regarding age and locality. It also includes mostly older people ( $83 \%$ of the cluster is older than 40 ) and those living in the countryside or small towns. Geographically, it is most probable (30\%) that individuals would fit the "inactive" cluster if they come from Košice or Prešov Region, which were the less-developed regions in the country at that time. The probability is only $19 \%$ when the respondents are from the Bratislava Region and $20 \%$ from Central Slovakia. The probability of belonging to this cluster is similar for male and female respondents (around $40 \%$ for males and $60 \%$ for females). In comparison to Cluster 1 , the most distinctive patterns are visible with regards to education. This cluster is mostly made up of people who have primary education, compared to the other clusters that have higher levels of education $(75 \%$ probability of low economic status). In the observed period, the number of respondents with this 
status increased from 2007 to 2013 and the probability of each of the cultural activities (except using internet for cultural purposes) decreased.

Cluster 3-Culturally omnivorous (25\% respondents in 2007, 24\% respondents in 2013): The third cluster is made up of the typically culturally omnivorous respondents. They regularly go to high-brow cultural events. The probability of a member of this cluster visiting the opera or a ballet performance was almost $47 \%$ in 2013 , a concert $76 \%$, a play at the theatre $73 \%$, a library $58 \%$, and $80 \%$ for a museum or gallery. They also go to the cinema and visit cultural sites regularly. They are active in all forms of cultural participation. The probability that they would read more than two books in a year is $83 \%$. They are active in reading books, practicing amateur forms of culture, and using the internet for cultural purposes.

There is higher chance that there are more women in this cluster (63\% in 2013). This cluster mainly groups younger or middle-aged individuals with secondary school or university education, living in cities. Students have the highest chance of being in this cluster as well as people from Bratislava in 2007. Single people have the highest probability of belonging to this cluster (44\%). This cluster is also the most stable from the point of view of cultural activity and comparison of 2007 and 2013. It is only in the case of practicing amateur cultural activities that the probability decreased during this period.

Cluster 4 (23\% respondents in $2007,20 \%$ respondents in 2013$)$ : The fourth cluster is typically focused on popular cultural genres. Its members are rarely active in high-brow culture in that they do not go to operas or ballets. There is a low probability of visiting the theatre $(23 \%)$ or galleries $(14 \%)$. Rather, they focus on cinema and concerts (with popular music being most likely). In comparison to Clusters 1 and 3, they read less with the probability of them reading more than two books a year being only $16 \%$. This is similar to the level of the "inactive" members in Cluster 2 . This cluster is the youngest and there is a $75 \%$ probability of people being younger than 39 . The probability of them having secondary school education is $71 \%$. People from bigger cities, especially from the Bratislava Region (almost 55\%) were most likely to belong to this cluster in 2013. This cluster has been called "focused on popular cultural genres". This was emphasized even more in 2013, visible in the number of visits to the cinema and concerts.

From the data in 2013, the number of visits to seven types of cultural events were calculated to create clusters and compare the typology of Slovakia with studies from other countries. The typology consisted of four clusters with similar profiles (only distinguished by the size of the clusters). In a similar way to other research, two stable groups of participants were identified in Slovakia. These are the cultural "omnivores" who actively participate in all forms of culture and the culturally "inactive". The cluster of the "inactive" is made up of $31 \%$ and the "omnivores" of $18 \%$. These two clusters have also been present in Scotland (Widdop and Cutts 2011), (the inactive made up 31\% and the omnivores $26 \%$ ), as well as research into Flemish cultural participation where $37 \%$ were in the "inactive" cluster (Vander Stichele and Laermans 2006). Research in Spain has shown a much bigger size of the "inactive" cluster-67\% (Sintas and Álvarez 2002). The size of the "omnivore" cluster is comparable with other studies (12\% in Spain, 28\% in Flanders, and 28\% in Scotland). As individuals from smaller towns and countryside participate in cultural events less often, the level of cultural participation at the national level is influenced by the spatial structures (the ratio of country/city).

\section{Discussion}

This paper adds to the theory of cultural participation by analyzing a typology of cultural participation in relation to economic conditions and education in Slovakia. The study has identified four clusters of individuals based on their participation in culture: The occasional visitors of historical sites and libraries, the inactive, the cultural omnivores, and those focused on popular forms of culture.

The four identified clusters are defined by age and education, which relates to economic status. In terms of regional influence, it can be seen that the respondents from Central Slovakia were more likely to be culturally omnivorous. These towns in Central Slovakia (Banská Bystrica, Banská Štiavnica) have always been traditionally cultural. However, the available data do not allow us to assess the 
spatial aspects of cultural participation. As such, this could be a topic of further research. Gender was only identified as a significant variable in the first cluster, showing a much higher probability of males. Females are more likely to consume high-brow culture then males, which was evident in the cluster analysis.

When comparing the profiles of the clusters between the years 2007 and 2013, their characteristics remain very similar. The first two clusters are characterized by lower cultural participation and the second two clusters by higher participation. The first two clusters are defined by people who are older, less educated, and live in small towns or the countryside while the second two clusters contain people who are younger, more educated and come from cities. The cluster analysis has shown the importance of age being included in the cluster. The impact of age in the model was mainly evident in the preferences of popular genres and the use of the internet for cultural purposes.

The study has also confirmed the influence of education on the cultural participation of individuals. A higher level of education is followed by higher economic status or social class. The lower the level of education, the higher probability of being found in the "inactive "group. In contrast, the higher the education, the higher the probability of belonging to the culturally omnivorous group. This confirms the influence of social stratification on the consumption of cultural goods. Stratification is significant in terms of the lower social classes although the influence decreases with regards to the middle and higher social classes.

In comparison to the results in other countries e.g., Sintas and Álvarez (2002), Vander Stichele and Laermans (2006), Cluster 1 is the most present in Slovakia. This reflects the cultural patterns of living in the countryside and smaller towns. This cluster has been compared to the type of cultural consumers who have been considered "low-brow omnivores" in some studies. These people combine the occasional visit of higher forms of culture with more regular visits to popular genres. However, Cluster 1 in the current study has had none of these preferences-neither popular genres nor high-brow forms of culture. Instead, easily accessible forms of culture (TV, radio, books) and historical sites were mostly identified. Moreover, there was no significant cluster of high-brow culture participants, which is usually identified in similar research at a national level. The data could not reveal the larger impact of Bratislava or Košice as the largest cities in the country (more than 100,000 inhabitants).

The analysis of cultural participation in Slovakia has shown that Bourdieu's theory about the elite social class consuming high-brow culture to declare its social position cannot be demonstrated in Slovakia. The model by Peterson and Simkus (1992) could also be fitting because of the available data that cannot be detailed enough to describe the habitual differences of lifestyles with cultural specificities. Art and culture practiced in the public sphere might not be attractive for the low-quality of institutions which have not "raised their audiences" in the last 30 years. The political value of culture and the systematic support of cultural participation have been neglected in cultural policies in the post-socialist context. Therefore, the theoretical frameworks of the original samples in France do not match those in Slovakia. The historical development of the elite in Slovakia has had completely different structure, with ideological and political ruptures causing changes in social structures.

In a similar way to empirical studies in other countries, it can be concluded that the exclusive connection between social position and high-brow (elite) culture is not well-founded. However, it does not mean that social class does not impact cultural participation. The intensity of cultural participation is largely influenced by education, income, and location. It is education and income that mainly form social stratification by adding to the typology of cultural consumption. The impact of a self-identified social class and character and intensity of cultural participation of individuals is stronger when looking at those who identify as working class. People who identify as working class with weak economic status and low education are usually culturally inactive and very rarely consume culture. If they do, then it is mainly though audiovisual media with some consumption of popular cultural genres. People in middle and higher social classes have different patterns of cultural behavior, which are not only formed by education or income, but also by other factors such as gender and living in a city. 
People with university education are also consumers of popular cultural genres. They have wider taste, which is demonstrated in all fields of cultural participation.

The comparison has shown that the reviewed time span was not enough long to explore the changes in cultural participation. Even the financial crisis and presence of European Capital of Cultural in the country did not significantly affect the data about cultural participation at the national level.

The impact of austerity measures and the financial crisis has not been visible in the examined period perhaps because Slovakia has suffered from austerity measures in culture since its independence (Denel 2003). It would be worth comparing the results from the next Eurobarometer dedicated to cultural participation in order to shed light on the impacts on cultural participation following the period of cultural policy after 2014. This period is associated with a broader approach, increase of financial and institutional support, and development of creative industries. In 2017, the Institute for Cultural Policy at the Ministry of Culture was established. Its first report was published in 2020 and strongly focused on revising expenditures in the cultural sector.

Our research is a starting point for an understanding of the typology of cultural participation. Many questions of cultural participation research have not yet been discussed in Slovakia and thus there is a continuous need for more exploratory research. There is also a need to formulate new cultural policy and strategy, which will take aspects of audience development and the multidimensionality of the choice to participate in culture into consideration.

Author Contributions: Conceptualization, M.Š.; data curation, M.Š.; formal analysis, M.Š.; funding acquisition, M.Š.; methodology, M.Š.; writing—original draft, Z.R. All authors have read and agreed to the published version of the manuscript.

Funding: This paper was supported by the Scientific Grant Agency of the MSVVaS SR project No. VEGA 1/0806/18.

Conflicts of Interest: The authors declare no conflict of interest.

\section{References}

Bihagen, Erik, and Tally Katz-Gerro. 2000. Culture consumption in Sweden: The stability of gender differences. Poetics 27: 327-49. [CrossRef]

Bourdieu, Pierre. 1984. Distinction: A Social Critique of the Judgement of Taste. Cambridge: Harvard University Press.

Brook, Orian. 2016. Spatial equity and cultural participation: How access influences attendance at museums and galleries in London. Cultural Trends 25: 21-34. [CrossRef]

Bukodi, Erzsébet. 2007. Social Stratification and Cultural Participation in Hungary: A Post-Communist Pattern of Consumption? EUI Working Papers. Italy: European University Institute, ISSN 1830-7728.

Chan, Tak Wing, and John H. Goldthorpe. 2007. Social stratification and cultural consumption: The visual arts in England. Poetics 35: 168-90. [CrossRef]

Chorvát, Ivan. 2011. Vol'ný čas na Slovensku v sociologickej perspektíve. In Vol'nočasové aktivity obyvatel'ov Slovenska—poznatky z aktuálnych vúskumov. Bratislava: Sociologický ústav SAV.

Chorvát, Ivan, and Jiří Šafr. 2020. Volný čas, společnost, kultura. Praha: SLON.

Coulangeon, Philippe. 2005. Educational Attainment and Participation in 'Highbrow Culture'. A Comparative Approach in European Union. Paris: CNRS (National Center for Scientific Research).

CVTISR. 2020. Centrum vedeckotechnických informácii SR. Bratislava: Útvar informácií a prognóz školstva., s.l.: S.n.

De Graaf, Nan Dirk. 1991. Distinction by Consumption in Czechoslovakia, Hungary and the Netherlands. European Sociological Review 7: 267-90. [CrossRef]

Delrieu, Varina, and Lisanne Gibson. 2017. Libraries and the geography of use: How does geography and asset "attractiveness" influence the local dimensions of cultural participation? Cultural Trends 26: 18-33. [CrossRef]

Denel, Francis. 2003. The National Cultural Policy of the Slovak Republic. Strasbourg: Council of Europe.

DiMaggio, Paul. 1982. Cultural Capital and School Success: The Impact of Status Culture Participation on the Grades of U.S. High School Students. American Sociological Review 47: 189-201. [CrossRef]

Eurobarometer. 2007. Cultural Values, Poverty and Social Exclusion, Developmental Aid, and Residential Mobility-Eurobarometer 67.1. Brusels: European Commission.

Eurobarometer. 2013. Cultural Access and Participation—Special Eurobarometer 399. Brussels: European Commission. 
Falk, Martin, and Tally Katz-Gerro. 2015. Cultural participation in Europe: Can we identify common determinants? Journal of Cultural Economics 40: 127-62. [CrossRef]

Gerhards, Jürgen. 2008. Die kulturell dominierende Klasse in Europa: Eine vergleichende Analyse der 27 Mitgliedsländer der Europäischen Union im Anschluss an die Theorie von Pierre Bourdieu. Kolner Zeitschrift fur Soziologie und Sozialpsychlogie 60: 723-48. [CrossRef]

Hallmann, Kirstin, Cristina Muñiz Artime, Christoph Breuer, Sören Dallmeyer, and Magnus Metz. 2017. Leisure participation: Modelling the decision to engage in sports and culture. Journal of Cultural Economics 41: 467-87. [CrossRef]

Hudec, Oto, Peter Džupka, Miriam Šebová, and Barbora Gontkovičová. 2015. Evaluácia Košice Európske hlavné mesto kultúry 2013. Košice: Evaluation Report of Košice ECoC 2013.

Jancovich, Leila, and David Stevenson. 2019. The "problem" of participation in cultural policy. In Cultures of Participation: Arts, Digital Media and Cultural Institutions. London: Routledge, pp. 167-84.

Katz-Gerro, Tally. 2011. Cross-National Cultural Consumption Research: Inspirations and Disillousions. Kölner Zeitschriftfür Soziologie und Sozial psychologie 51: 339-60.

Katz-Gerro, Tally. 2017. Cross-National Differences in the Consumption of Non-National Culture in Europe. Cultural Sociology 11: 438-67. [CrossRef]

Kraaykamp, Gerbert, and Paul Nieuwbeerta. 2000. Parental Background and Lifestyle Differentiation in Eastern Europe: Social, Political, and Cultural Intergenerational Transmission in Five Former Socialist Societies. Social Science Research 29: 92-122. [CrossRef]

Lauko, Viliam, Daniel Gurňák, František Križan, and Ladislav Tolmáči. 2012. Najnovšie vývojové trendy vzdelanostnej štruktúry obyvatel’stva Slovenska v časovo-priestorových súvislostiach. Geographia Cassoviensis 6: 91-102.

López-Sintas, Jordi, and Tally Katz-Gerro. 2005. From exclusive to inclusive elitists and further: Twenty years of omnivorousness and cultural diversity in arts participation in the USA. Poetics 33: 29-319. [CrossRef]

Magidson, Jay, and Jeroen Vermunt. 2002. Latent class models for clustering: A comparison with K-means. Canadian Journal of Marketing Research 20: 36-43.

Mihelj, Sabina, Adrian Leguina, and John Downey. 2019. Culture is digital: Cultural participation, diversity and the digital divide. New Media and Society 21: 1465-85. [CrossRef]

Notten, Natascha, Bram Lancee, Herman G. van de Werfhorst, and Harry B. G. Ganzeboom. 2015. Educational stratification in cultural participation: Cognitive competence or status motivation? Cultural Economics 39: 177-203. [CrossRef]

O'Hagan, John. 2017a. Attendance at/Participation in the Arts by Educational Level: Evidence and Issues. Edited by Victoria M. Ateca-Amestoy, Victor Ginsburgh, Isidoro Mazza, John O’Hagan and Juan Prieto-Rodriguez. Cham: Springer, pp. 51-66.

O'Hagan, John. 2017b. European Statistics on Participation in the Arts and Their International Comparability. In Enhancing Participation in the Arts in the EU. Cham: Springer, pp. 3-18.

OECD. 2014. Education at a Glance 2014. Paris: Country Note Slovak Republic.

Peterson, Richard A., and Albert Simkus. 1992. How musical tastes mark occupational status groups. In Cultivating Differences. Chicago: University of Chicago Press, pp. 152-86.

Purhonen, Semi, Jukka Gronow, and Keijo Rahkonen. 2011. Highbrow culture in Finland: Knowledge, taste and participation. Acta Sociologica 54: 385-402. [CrossRef]

Reeves, Aaron. 2014. Neither Class nor Status: Arts Participation and the Social Strata. Sociology 49: 624-42. [CrossRef]

Roose, Henk, Koen van Eijck, and John Lievens. 2012. Culture of distinction or culture of openness? Using a social space approach to analyze the social structuring of lifestyles. Poetics 40: 491-513. [CrossRef]

Šafr, Jiří. 2006. Social Standing and Lifestyle in Czech Society. Prague: Institute of Sociology of Czech Academy of Sciences.

Šebová, Miriam. 2017. Ekonomické a sociálne dimenzie kultúry v meste. Habilitačná práca (Economic and Social Dimensions of Culture in the City. Habilitation thesis). Ph.D. thesis, Technická univerzita v Košiciach, Košice, Slovakia; 228p.

Sintas, Jordi López, and Ercilia Garcia Álvarez. 2002. Omnivores Show up Again: The Segmentation of Cultural Consumers in Spanish Social Space. European Sociological Review 18: 353-68. [CrossRef] 
Suarez-Fernandez, Sara, Juan Prieto-Rodriguez, and Maria Jose Perez-Villadoniga. 2020. The changing role of education as we move from popular to highbrow culture. Journal of Cultural Economics 44: 189-212. [CrossRef]

van Hek, Margriet, and Gerbert Kraaykamp. 2013. Cultural consumption across countries: A multi-level analysis of social inequality in highbrow culture in Europe. Poetics 41: 323-41. [CrossRef]

Van Rees, Kees, Jeroen Vermunt, and Marc Verboord. 1999. Cultural classifications under discussion: Latent class analysis of highbrow and lowbrow reading. Poetics 26: 349-65. [CrossRef]

Vander Stichele, Alexander, and Rudi Laermans. 2006. Cultural participation in Flanders: Testing the cultural omnivore thesis with population data. Poetics 34: 45-64. [CrossRef]

Vojtíšková, Kateřina, and Radmila Lorencová. 2014. Public funding of culture in the Czech Republic since the fall of the iron curtain: Contemporary dilemmas. International Journal of Cultural Policy 21: 529-53. [CrossRef]

Warde, Alan, David Wright, and Modesto Gayo-Cal. 2007. Understanding Cultural Omnivorousness: Or, the Myth of the Cultural Omnivore. Cultural Sociology 2: 143-64. [CrossRef]

Weingartner, Sebastian, and Jörg Rössel. 2019. Changing dimensions of cultural consumption? The space of lifestyles in Switzerland from 1976 to 2013. Poetics 7: 1-16. [CrossRef]

Widdop, Paul, and David Cutts. 2011. Cultural Consumption in Scotland. In Analysis of the Scottish Households Survey Culture Modul. Manchester: Institute for Social Change, University of Manchester, Scottish Government Social Research.

Wolfe, Johne. 1970. Pattern Clustering by Multivariate Mixture Analysis. Multivariate Behavioral Research 5: 329-50. [CrossRef] [PubMed]

Publisher's Note: MDPI stays neutral with regard to jurisdictional claims in published maps and institutional affiliations.

(C) 2020 by the authors. Licensee MDPI, Basel, Switzerland. This article is an open access article distributed under the terms and conditions of the Creative Commons Attribution (CC BY) license (http://creativecommons.org/licenses/by/4.0/). 